\title{
Pengembangan Agroekowisata Terintegrasi di Lahan Gambut Di Kalimantan Tengah
}

\author{
Adi Jaya, Emmy Uthanya Antang, Cakra Birawa, Lilies Supriati, Salampak \\ dan Haris Gunawan \\ ${ }^{1}$ Fakultas Pertanian, Universitas Palangka Raya \\ ${ }^{2}$ Universitas Riau, Pekanbaru \\ Email : adijaya@agr.upr.ac.id
}

\begin{abstract}
Abstrak
Kegiatan yang dilakukan pada Kawasan Kanal Kalampangan, Blok C eks PLG, lebih diarahkan pada kegiatan restorasi gambut untuk mendukung pengembangan kegiatan ekowisata dengan memanfaatkan berbagai potensi yang ada di kawasan ini. Posisi kawasan yang tidak jauh dari Palangka Raya, menjadikan lokasi ini penting dan mempunyai keunggulan. Kegiatan yang dikembangkan pada dasarnya sebagai wahana pendidikan tentang gambut yang akan meliputi pemahaman sifat dan ciri gambut, pemanfaatan lahan gambut (utamanya untuk kegiatan pertanian) dan dampak lingkungan yang ditimbulkan serta kegiatan restorasi gambut. Semua objek yang rencananya ditampilkan dalam jalur jalan sepanjang 5-6 km tersebut, diinisiasi melalui pendanaan dari BRG dan selanjutnya diharapkan para stakeholder terkait gambut melakukan investasi dengan membangun sarana wisata tersebut. Hakekat dari kegiatan agroekowisata, selain sebagai wahana pendidikan, juga diharapkan masyarakat di kawasan tersebut menjaga kawasan gambut dari kerusakan terutama akibat kebakaran hutan dan lahan yang terjadi setiap musim kemarau. Kegiatan awal yang dilakukan dengan pendanaan dari BRG mencakup 3R yakni rewetting, revegetasi dan revitalisasi ekonomi masyarakat.
\end{abstract}

Kata Kunci : agroekowisata, gambut, restorasi, pemberdayaan masyarakat

\section{Pendahuluan}

Lahan gambut merupakan ekosistem alami penting dengan nilai tinggi untuk konservasi keanekaragaman hayati, pengaturan iklim, dan kesejahteraan manusia. Indonesia merupakan negara terbesar keempat di dunia untuk cadangan gambut dengan luas diperkirakan sekitar 20,6 juta ha, yang tersebar terutama di Sumatra, Kalimantan, dan Papua. Dalam kondisi alami, salah satunya adalah fungsi yang terkait jasa lingkungan. Kawasan gambut khususnya di Kalimantan Tengah, cukup banyak yang mengalami degradasi oleh berbagai sebab diantaranya adalah akibat kebakaran hutan dan lahan rawa gambut. Kebakaran hutan dan lahan Tahun 2015 merupakan kebakaran hutan dan lahan yang cukup parah dan lama, dan akibat dari kebakaran lahan tersebut makin meluas. Pemerintah Indonesia melalui Peraturan Presiden Nomor 1 Tahun 2016, telah membentuk Badan Restorasi Gambut untuk tujuan melakukan konservasi dan restorasi lahan gambut terdegradasi. Peraturan Pemerintah (PP) Nomor 71 Tahun 2014 tentang Perlindungan dan pengelolaan
Ekosistem Gambut dan PP Nomor 57 Tahun 2016 tentang Perubahan atas Peraturan Pemerintah Nomor 71 Tahun 2014 Tentang Perlindungan dan Pengelolaan Ekosistem Gambut, menjadi dasar utama pelaksanaan kegiatan yang berkaitan dengan ekosistem gambut, termasuk kegiatan restorasi gambut yang rusak.

Secara umum pendekatan terpadu (terintegrasi) harus dilakukan untuk konservasi dan restorasi lahan gambut terdegradasi sebagaimana menjadi program BRG yaitu 3R dengan mencakup aspek : restorasi hidrologi (re-wetting) dan revegetasi, pemberdayaan ekonomi masyarakat (revitalisasi livelihood) serta penyiapan tim pencegahan dan penanggulangan kebakaran hutan dan lahan. Restorasi hidrologi bertujuan untuk memberikan kesempatan pada lahan gambut untuk dibasahkan kembali sehingga peluang terjadinya kebakaran hutan menjadi kecil, selain juga dapat memberikan kondisi tanah yang baik bagi pertumbuhan vegetasi. Restorasi vegetasi dilakukan dengan cara penanaman kembali spesies endemik di 
kawasan hutan dan lahan rawa gambut. Namun secara umum teknik perbanyakan dan budidaya pohon spesies lokal tingkat keberhasilannya masih rendah. Oleh karena itu perlu dikaji teknik perbanyakan cepat dan teknik budidaya untuk memenuhi kebutuhan bibit pohon endemik agar target restorasi lahan gambut yang telah ditetapkan pemerintah Indonesia dapat terpenuhi.

Pemberdayaan ekonomi masyarakat masyarakat melalui berbagai kegiatan budidaya tanaman bernilai ekonomis, budidaya ikan, budidaya lebah dll dimaksudkan agar masyarakat tidak melakukan aktivitas perambahan hutan yang juga menyebabkan degradasi hutan dan lahan rawa gambut dan bahkan dapat diarahkan untuk menjaga kawasan hutan apabila mereka memiliki pendapatan tetap untuk kebutuhan ekonomi mereka. Untuk masa depan, kegiatan memanfaatkan nilai jasa lingkungan kawasan hutan sebagai bagian wisata perlu dipertimbangkan.

Melihat potensinya, kawasan yang dijadikan sebagai kawasan restorasi gambut diarahkan untuk kegiatan ekowisata akan menggambarkan tentang gambut dan segala pemanfaatan serta dampak lingkungan yang ditimbulkan, termasuk di dalamnya kegiatan restorasi lahan gambut yang mengedepankan konsep 3R. Secara hakekat, maka agar lokasi ekowisata dapat aman dari persoalan kerusakan terutama kebakaran hutan dan lahan, maka masyarakat akan berusaha menjaga kawasan tersebut.

Kawasan gambut di Kalimantan Tengah saat ini belum dimanfaatkan dengan optimal. Kebijakan-kebijakan pemerintah daerah yang dituangkan dalam RTRWK menjadi penting untuk diperhatikan bila dikaitkan dengan keberlanjutan kawasan lahan gambut ini di masa datang. Upaya mempertahankan keberlanjutan Kawasan lahan gambut di Kalimantan Tengah dan sekaligus pemanfaatannya sebagai sumber informasi dan edukasi dapat dicapai dengan merencanakan pengembangan kawasan untuk kegiatan wisata dengan konsep ekowisata dikombinasikan dengan aspek wisata lainnya termasuk agro wisata dan wisata budaya.

Berdasarkan latar belakang dan perumusan masalah yang telah diuraikan maka tujuan Kegiatan ini adalah sebagai berikut:

1. Mengidentifikasi dan menganalisis potensi objek dan daya tarik wisata alam dan wisata lainnya di wilayah gambut KHG Kahayan Sebangau termasuk potensi sosial budayanya, khususnya untuk Kawasan Misik, Kelurahan Kalampangan.

2. Mengetahui persepsi masyarakat, pengunjung dan lembaga terkait mengenai kegiatan ekowisata alam dan wisata lainnya di wilayah gambut KHG Kahayan Sebangau, khususnya Kawasan Misik.

3. Merumuskan strategi pengembangan ekowisata yang berkelanjutan di wilayah gambut di KHG Kahayan Sebangau, khususnya Kawasan Misik.

\section{Pelaksanaan Kegiatan Lokasi Kegiatan}

Kegiatan dilakukan pada kawasan gambut yang berada di Kawasan Misik, Blok C Eks PLG. Wilayah Kegiatan termasuk dalam KHG Kahayan Sebangau. Secara administratif, lokasi Kegiatan berada di Kelurahan Kalampangan, Kota Palangka Raya.

\section{Tahapan Kegiatan}

\section{Tahap I: Pengumpulan Data}

Data yang dikumpulkan berupa data primer dan data sekunder. Pengumpulan data primer dilakukan dengan 2 cara, yaitu: survei terhadap masyarakat, dan Focus Group Discussion (FGD) terhadap tokoh masyarakat yang ada pada Kelurahan Kalampangan, Kelurahan Kameloh, dan Desa Tanjung Taruna. Penetapan Kelurahan Kameloh Baru dan Desa Tanjung Taruna sebagai lokasi survei dengan pertimbangan bahwa untuk kunjungan wisata diperlukan lokasi kawasan wisata alternatif yang berdekatan, dan kedua kelurahan/desa tersebut termasuk kawasan lahan gambut dengan ekosistem yang berbeda, sehingga obyek wisata yang dimiliki berbeda. 
Survei dilakukan terhadap 75 orang penduduk/masyarakat yang tinggal di Kelurahan Kalampangan, Kelurahan Kameloh Baru, dan Desa Tanjung Taruna, dengan jumlah masing-masing 25 orang pada setiap kelurahan/desa. Sedangkan FGD dilakukan terhadap 10-15 orang tokoh masyarakat dari setiap kelurahan/desa.

\section{Tahap II: Pengolahan Data}

Data yang terkumpul dilakukan pengolahan dengan melakukan tabulasi dan pengklasifikasian sesuai dengan kebutuhan analsis data.

\section{Tahap III: Analisis Data}

Analisis data untuk kajian potensi ekowisata dilakukan dengan analisis deskriptif kualitatif, yaitu untuk untuk mendiskripsikan potensi wisata di Kawasan Misik. Sedangkan untuk analisis strategi pengembangan potensi ekowisata digunakan analsis SWOT (Rangkuti, 1997).

\section{Rencana Jangka Panjang Pengembangan Ekowisata Restorasi Gambut}

Secara umum kawasan agroekowisata pendidikan restorasi gambut, direncanakan dikembangkan menjadi wilayah dengan berbagai kegiatan. Konsultasi dan komunikasi telah dilakukan dengan pihak Pemerintah Kota Palangka Raya dan melalui diskusi dengan Walikota dan Wakil Wali Kota Palangka Raya. Kawasan ini merupakan Kawasan Strategis Pariwisata (KSP)-4 dalam RIPP Kota Palangka Raya.

Rencana Kegiatan Implementasi Restorasi Gambut Terintegrasi Tahun 2018

\section{a. Kegiatan Tahun 2017}

Adapun kegiatan yang terkait restorasi gambut terintegrasi untuk mendukung pengembangan ekowisata yang telah dilakukan melalui pendanaan BRG Tahun 2017 adalah :

\begin{tabular}{|c|c|c|}
\hline Kegiatan & Uraian & Capaian \\
\hline \multirow[t]{2}{*}{$\begin{array}{l}\text { Sosialisasi dan } \\
\text { Workshop }\end{array}$} & $\begin{array}{l}\text { Sosialisasi dan FDG tentang } \\
\text { Restorasi Gambut }\end{array}$ & Selesai \\
\hline & $\begin{array}{l}\text { Workshop tentang Pengembangan } \\
\text { Ekowisata }\end{array}$ & Selesai \\
\hline Pembasahan (P1) & $\begin{array}{l}\text { a. Terbangunnya } 8 \text { unit dam di } \\
\text { Kanal tersier di sekitar Kanal } \\
\text { Kalampangan. } \\
\text { b. Tersedianya } 200 \text { titik } \\
\text { pemantauan TMA } \\
\text { c. Membuat sumur bor sebanyak } \\
10 \text { titik dengan } 1 \text { buah mesin } \\
\text { pompa air }\end{array}$ & $\begin{array}{l}\text { a. Terbangun } 8 \text { buah sekat kanal } \\
\text { si saluran sekunder dan } 1 \text { buah } \\
\text { di saluran lahan petani } \\
\text { b. Terbangun transek } \\
\text { pengamatan TMA } \\
\text { c. Selesai } 10 \text { titik dan tersedia } \\
\text { satu set perlengkapan } \\
\text { pemadaman kebakaran }\end{array}$ \\
\hline $\begin{array}{l}\text { Penanaman } \\
\text { kembali (P2) }\end{array}$ & $\begin{array}{l}\text { Penanaman pohon endemik } \\
\text { kawasan gambut sebanyak } 13.000 \\
\text { pohon (sekitar } 10 \text { ha) }\end{array}$ & $\begin{array}{l}\text { a. Dengan pola tumpang sari } \\
\text { dengan buah naga, tertanam } \\
\text { untuk seluas } 1,5 \text { ha, } \\
\text { b. Penanaman pada tanggul } \\
\text { kanal dan lahan masyarakat }\end{array}$ \\
\hline \multirow[t]{3}{*}{$\begin{array}{l}\text { Penguatan } \\
\text { ekonomi } \\
\text { Masyarakat (P3) }\end{array}$} & $\begin{array}{l}\text { a. Budidaya tanaman sayuran } \\
\text { dan buah-buahan }\end{array}$ & $\begin{array}{l}\text { Sebanyak } 15 \text { orang petani terlibat } \\
\text { kegiatan budidaya sayudan dan } \\
\text { buah-buahan semusim }\end{array}$ \\
\hline & b. Budidaya cacing tanah. & $\begin{array}{l}1 \text { orang petani pada tahap } 1 \text { dan } 1 \\
\text { orang petani pada Tahap } 2\end{array}$ \\
\hline & $\begin{array}{l}\text { c. Dibangunnya beberapa sarana } \\
\text { ekowisata }\end{array}$ & $\begin{array}{l}\text { Terbangun } 3 \text { unit gazebo dan } 2 \\
\text { unit rakit/perahu wisata }\end{array}$ \\
\hline
\end{tabular}




\begin{tabular}{|c|c|c|}
\hline & $\begin{array}{l}\text { d. } \begin{array}{l}\text { Budidaya ikan dalam areal } \\
\text { perairan hasil sekat kanal }\end{array} \\
\text { e. Budidaya bebek dalam } \\
\text { kawasan kebun Jelutung } \\
\text { dengan sistim silvopastura } \\
\text { Budidaya lebah madu dalam areal } \\
\text { petani yang menerapkan sistiem } \\
\text { tumpangsari buah naga dan } \\
\text { tanaman Jelutung }\end{array}$ & $\begin{array}{l}\text { Terbangun } 3 \text { unit karamba dan } \\
\text { dilakukan budidaya ikan lokal } \\
\text { Sudah terlaksana, di lokasi milik } \\
\text { Pa Parni di Desa Kalampangan } \\
\text { Sudah terlaksana dengan } \\
\text { penempatan } 2 \text { unit lebah madu }\end{array}$ \\
\hline $\begin{array}{l}\text { Pencegahan dan } \\
\text { Pengendalian } \\
\text { Kebakaran Hutan } \\
\text { dan Lahan }\end{array}$ & $\begin{array}{l}\text { Terbentuknya unit pencegahan } \\
\text { dan pengendalian kebakaran hutan } \\
\text { dan lahan yang aktif }\end{array}$ & $\begin{array}{l}\text { Tersedia } 10 \text { titik sumur bor } \\
\text { Tersedia } 1 \text { (satu) set perlengkapan } \\
\text { mesin pompa air dan slang }\end{array}$ \\
\hline
\end{tabular}

\section{b. Kegiatan Tahun 2018}

Dalam rencana kegiatan Tahun 2018 yang diusulkan sebagai implementasi ekowisata di lahan gambut Kawasan Misik dibangun dan dilengkapi beberapa sarana ekowisata sederhana dan objek wisata pertanian, dilakukan hal-hal berikut:

\begin{tabular}{|c|c|}
\hline Komponen: & Kegiatan: \\
\hline Pembasahan (P1) & $\begin{array}{l}\text { Rehabilitasi atau perbaikan sekat kanal yang telah dibangun pada tahun } \\
2017\end{array}$ \\
\hline $\begin{array}{l}\text { Penanaman } \\
\text { kembali (P2) }\end{array}$ & $\begin{array}{l}\text { Penanaman pohon endemik kawasan gambut sebanyak } 2.000 \text { pohon } \\
\text { ditambah dengan pohon produktif seperti cempedak }\end{array}$ \\
\hline $\begin{array}{l}\text { Penguatan } \\
\text { ekonomi } \\
\text { Masyarakat (P3) }\end{array}$ & $\begin{array}{l}\text { a. Budidaya tanaman yang sifatnya tidak berbasis eksploitasi lahan } \\
\text { seperti : jamur tiram, kopi. } \\
\text { b. Budidaya cacing tanah. } \\
\text { c. Dibangunnya beberapa sarana ekowisata: taman tanaman hias } \\
\text { seperti anggrek, pinang, bantuan bahan untuk } 6 \text { unit gazebo, } 2 \text { unit } \\
\text { WC umum dan } 2 \text { unit rakit wisata } \\
\text { d. Budidaya sistem tumpangsari buah naga, tanaman hortikultura dan } \\
\text { tanaman Jelutung } \\
\text { e. Budidaya Melon, dan Butternut suash } \\
\text { f. Pengembangan SDM di kawasan ekowisata: melalui kegiatan } \\
\text { gosialisasi Budaya Wisata, dan Pelatihan Pemandu Wisata } \\
\text { g. Ujicoba kunjungan wisata }\end{array}$ \\
\hline
\end{tabular}

\section{Hasil Kegiatan dan Pembahasan \\ Sosialisasi dan kegiatan pendukung}

Sosialisasi kegiatan terkait dengan rencana kajian potensi ekoswisata terintegrasi di kawasan Kampung Misik, Kelurahan kalampangan dilaksanakan di rumah Ketua RT 7, bersamaan dengan rapat masyarakat pada tanggal 7 Juli 2018. Peserta yang hadir adalah masyarakat yang berada di sekitar lokasi kegiatan, yaitu masyarakat RT 7 dan tokoh masyarakat.
Dalam kegiatan ini disampaikan :

1. Gambut dan Permasalahannya sehingga perlu dilakukan restorasi.

2. Program yang akan dilakukan dalam Kegiatan Kajian Potensi Ekowisata Terintegrasi. 


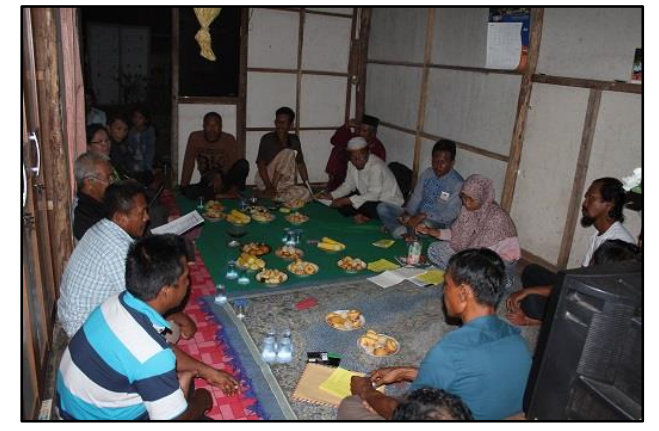

Gambar 1. Sosialisasi kegiatan bersamaan dengan rapat RT7 Kampung Misik

Program yang direncanakan dalam imlementasi Kajian Potensi Ekowisata terintegrasi merupakan hasil diskusi dengan tokoh masyarakat setempat pada saat dilakukan survei pendahuluan, yang kemudian disosialisasikan kepada seluruh masyarakat di Kawasan Misik dan disepakati bersama pelaksanaannya.

\section{Penguatan Ekonomi}

Penguatan ekonomi yang dilakukan pada kawasan Misik diarahkan untuk mendukung pengembangan kawasan menjadi lokasi atau daerah tujuan wisata, dengan menjadikan kegiatan ekonomi masyarakat sebagai salah satu daya tarik wisata.

\subsection{Pelatihan dan Budidaya Jamur Tiram}

Kegiatan budidaya jamur tiram dimulai dengan melakukan pelatihan budidaya jamur tiram kepada kelompok masyarakat yang berjumlah 10 orang. Pelatihan yang diberikan oleh instruktur terlatih dan berpengalaman serta pelaku usaha jamur tiram disertai dengan praktek budidaya jamur tiram yang dimulai dari tahap persiapan, pembuatan dan sterilisasi baglog, sampai ada penanaman bibit jamur ke dalam baglog.

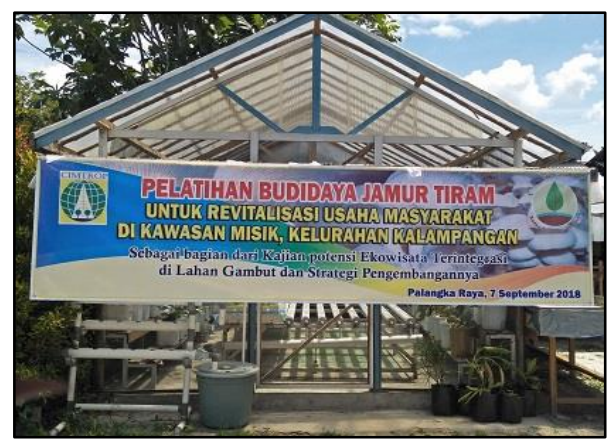

Gambar 2. Pelatihan dan Budidaya Jamur Tiram

\subsection{Budidaya Lebah Madu dan Pengolahan Limbah Sapi}

Budidaya lebah madu telah dimulai sejak pelaksanaan Pilot Project Restorasi Gambut Terintegrasi pada tahun 2017 pada kawasan Misik ini, dan telah memberikan hasil yang baik dengan pertumbuhan jumlah lebah yang sangat besar. Sampai dengan awal tahun 2018 jumlah lebah yang tumbuh pada kotak pemeliharaan/rumah lebah sangat pesat, sehingga semua kotak terisi penuh dan menghasilkan madu. Hal ini menunjukkan bahwa wilayah tersebut cocok sebagai tempat budidaya lebah madu, dan makanan untuk lebah tersedia karena kawasan ini merupakan lokasi budidaya sayur dan buah.

Selain memberikan keuntungan menghasilkan madu, keuntungan lain didapat pula dari pengembangan lebah madu ini, yaitu jumlah produksi sayur paria yang dimiliki salah satu petani memberikan hasil yang meningkat, yang diyakini oleh petani tersebut akibat adanya lebah madu pada sekitar lahan pertaniannya. Kendala yang dihadapi petani yang mengusahakan budidaya lebah madu adalah mahalnya harga kotak lebah madu lengkap dengan lebahnya, namun tidak memiliki pengetahuan untuk membuat perbanyakan kotak madu dan memindahkan lebah ke kotak yang baru.

Bekerjasama dengan Tim Restorasi Gambut Daerah (TRGD) Prov.Kalimantan Tengah, telah dilaksanakan pelatihan Budidaya Lebah Madu dan Pengolahan Limbah Sapi yang dilaksanakan untuk pengembangan ekonomi masyarakat di daerah Pulang Pisau dan Kalampangan khususnya Kawasan Jl. Misik.

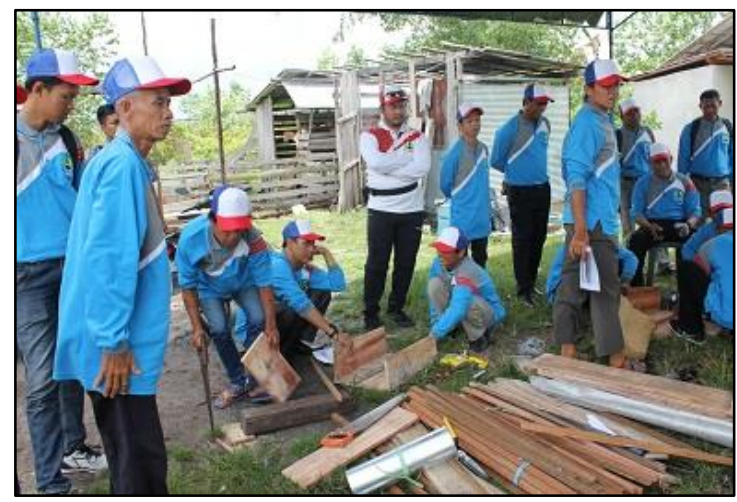

Gambar 3. Budidaya Lebah Madu 


\subsection{Budidaya Kopi, Lidah Buaya, Melon, dan Labu Madu (Butternut Squash)}

1. Kopi. Saat ini dikembangkan kopi yang dapat beradaptasi tumbuh pada dataran rendah dan di lahan gambut yaitu kopi liberika. Berdasarkan hasil Kegiatan, masyarakat Jambi telah mengembangkan kopi liberika dengan pola tanaman campuran dengan tanaman pinang dan kelapa, pasar terbuka luas, dan permintaan terhadap kopi liberika lebih besar dari produksinya.

Pada Kawasan Misik mulai dikembangkan tanaman kopi liberika, dengan memberikan 400 bibit. Penanaman tanaman kopi ini diharapakan untuk persiapan mendukung pengembangan pola agroforestry, terutama pola tanaman campuran dengan pohon endemik lokal seperti jelutung, ramin, balangeran yang ditanam oleh masyarakat sebagai bagian dari kegiatan revegetasi untuk restorasi gambut terintegrasi.

2. Lidah Buaya, salah satu tanaman yang dikembangkan pada kawasan ini. Pengalaman budidaya lidah buaya di kawasan gambut di Kalimantan Barat memberikan hasil yang baik, sehingga program Kajian Ekowisata terintegrasi menyediakan 200 bibit lidah buaya untuk dikembangkan di kawasan ini, dengan harapan pada masa yang akan datang menjadi salah satu obyek wisata dan dapat dikembangkan pengolahannya menjadi oleh-oleh, sehingga memberikan nilai tambah ekonomi bagi masyarakat di sekitarnya.

Keragaman jenis tanaman yang luas, akan memberikan daya tarik yang lebih luas dari kawasan misik, dan lidah buaya merupakan tanaman yang dapat dipanen kapan saja, sehingga sustainibiltasnya tetap terjaga.

3. Melon, salah satu jenis buah yang sudah dikembangkan oleh masyarakat setempat, namun yang dikembangkan adalah jenis melon kuning dan putih yang umum diperdagangkan. Program ini mengembangkan melon jenis yang lain, yaitu Golden Melon, yang diharapkan akan terus dikembangkan oleh sebagai variasi obyek dan daya tarik wisata petik buah yang sudah dikembangkan pada kawasan ini, dan memberikan hasil ekonomi yang baru bagi petani.

4. Labu Madu atau Butternut Squash, adalah salah satu jenis tanaman yang saat ini mulai banyak dikembangkan di Indonesia. Memiliki bentuk yang unik, dengan rasa manis dan tekstur yang lembut. Manfaat untuk kesehatan sangat besar, karena mengandung serat yang tinggi, dan mengandung antioksidan, beta karoten, vitamin A dan B kompleks, sehingga dapat mengontrol kadar gula darah, membantu mengobati penyakit anemia karena kandungan zat besinya yang tinggi, dan dapat digunakan untuk mengendalikan berat badan.

Program ini mengembangkan tanaman labu madu sebagai variasi tanaman buah yang dapat menjadi daya tarik bagi wisatawan petik buah, disamping itu dapat memberikan keuntungan ekonomi yang baik bagi petani karena belum dikembangkan di wilayah Kota Palangka Raya, dan harganya yang cukup tinggi.

\subsection{Budidaya Tumpang Sari Buah Naga,} Jelutung, dan Tanaman Hortikultura Pola agroforestry banyak dikembangkan saat ini, banyak fungsi dan manfaat yang didapat dari pengembangan agroforestry karena pola tanam antara tanaman tahunan (pohon) dengan tanaman setahun dan tanaman hortikultura, seperti pendapatan jangka pendek dari tanaman setahun dan hortikultura, serta manfaat perlindungan tanah dan air, perlindungan keanekaragaman hayatidan menjaga estetika lansekap.

Pola Agroforestry yang dikembangkan di Kawasan Misik adalah tumpang sari antara tanaman jelutung, Buah Naga, dan tanaman hortikultura berupa sayuran yang jenisnya berganti setiap musim tanam. Pada kegiatan ini stimulan diberikan kepada budidaya Buah Naga, tanaman jelutung merupakan kegiatan pilot project terintegrasi tahun 2018, dan tanaman 
hortikultura ditanam dengan swadaya dari petani.

1.5.Budidaya Cempedak dan Pinang. Tanaman lainnya yang dikembangkan di Kawasan Misik adalah cempedak dan pinang. Pertimbangan dari pengembangan budidaya tanaman ini adalah karena cempedak merupakan buah lokal yang baik untuk dikembangkan, sedangkan pinang memiliki prospek yang baik untuk dikembangkan, karena pinang merupakan salah satu komoditas yang dapat digunakan sebagai bahan baku obat dan kosmetik, baik untuk kebutuhan dalam negeri maupun ekspor. Dari segi tajuk, pohon pinang yang lurus baik pula sebagai bagian dari lansekap taman.

\section{Potensi Objek Wisata di Lahan Gambut}

Kampung Misik, yang merupakan bagian dari Kelurahan Kalampangan memiliki potensi besar untuk dikembangkan menjadi kawasan wisata, karena kekhasan ekosistem dan lingkungan lahan gambut yang dimiliki khas dan unik. Beberapa obyek wisata dapat dikembangkan pada kawasan ini, baik untuk wisata berbasis lingkungan atau ekowisata, maupun wisata Kegiatan atau pendidikan.

Salah satu cara untuk menilai potensi wisata pada suatu wilayah, Cooper, et al (2005) mengemukakan paling tidak ada 4 (empat) komponen yang harus dimiliki oleh obyek wisata, yang dikenal dengan istilah 4A, yaitu: attraction, accessibility, amenity dan ancilliary.

A. Attraction, atau atraksi, merupakan komponen yang penting sebagai daya tarik wisatawan untuk datang ke suatu kawasan wisata. Potensi atraksi wisata di Kawasan Misik dapat mencakup ketiganya, yaitu: berupa atraksi alami dalam bentuk landcape, dan ekologi gambut yang unik dan khas sehingga dapat menjadi daya tarik wisatawan untuk mengunjungi kawasan ini.

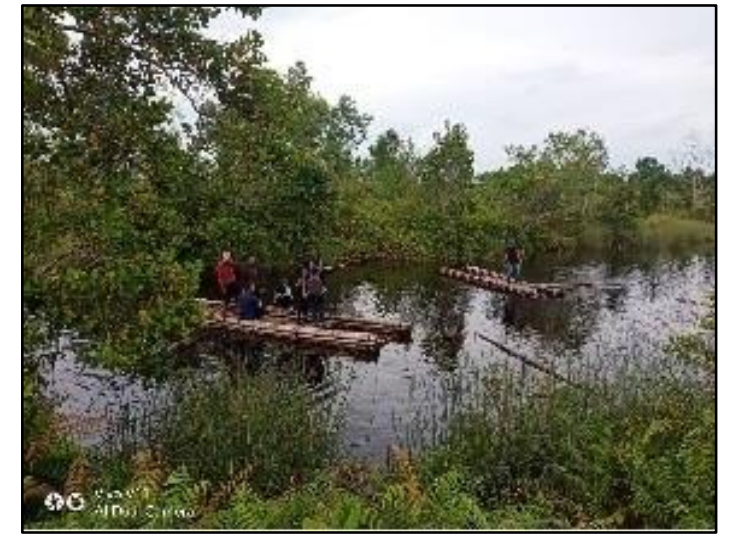

\section{Gambar 4. Atraksi dan Landskap Alami} Kawasan Gambut

Kawasan alam dapat dijadikan atraksi wisata petualangan, dimana wisatawan dapat menggunakan perahu kecil (jukung/kelotok, dan rakit) menyusuri kanal dan menikmati ekosistem gambut di sekitar kanal.

Potensi atraksi budaya dapat dikembangkan pada kawasan ini, yaitu tentang sejarah awal mula terbentuknya Kelurahan Kalampangan dengan segala kendala sampai keberhasilannya pada saat ini, museum dan galeri tentang gambut, yang dapat dijadikan sebagai bagian dari wisata pendidikan.

Atraksi buatan yang tersedia pada Kawasan ini dan memiliki potensi untuk dikembangkan adalah: susur Kanal dan melintas Dam, agroforestry, wisata petik buah, budidaya jamur tiram dan cacing tanah, dan pengembangan taman.

\section{a. Sekat Kanal}

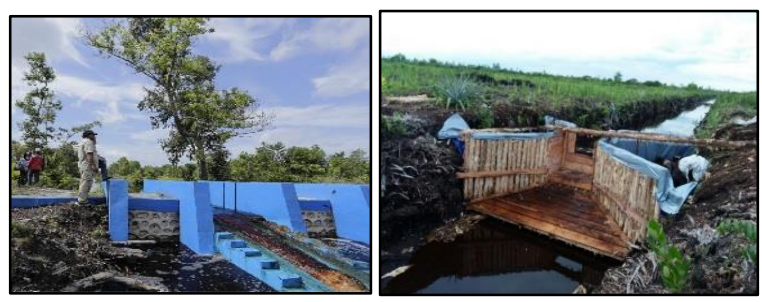

Gambar 5. Sekat kanal yang dibangun sebagai bagian restorasi hidrologi

Objek ini dibangun oleh Balai Rawa, Kementerian PUPR dan terdapat 3 unit di sepanjang kanal Kalampangan yang merupakan kawasan eks PLG yang dibangun Tahun 1996. Objek ini memperlihatkan upaya restorasi hidrologi (rewetting, R1). Selain itu melalui kegiatan pilot project yang didanai BRG pada Tahun 2017, dibangun 8 
unit sekat kanal di kanal yang berukuran lebar sekitar 4 meter di kawasan Kampung Misik.

Objek ini lebih menekankan pada aspek edukasi yang memperlihatkan bagimana dampak yang ditimbulkan oleh drainase tidak terkendali di kawasan gambut dan hasil yang dicapai oleh adanya restorasi hidrologi tersebut. Data memperlihatkan bahwa terdapat perbedaan tinggi muka air dikanal sekitar 25-50 cm antara kawasan hulu dan hilir sekat kanal.

\section{b. Agroforestry}

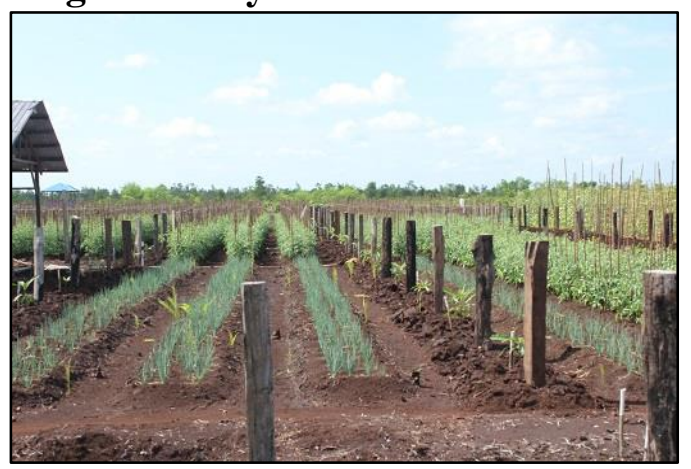

Gambar 6. Kegiatan Agroforestry yang sudah ada di Kampung Misik

Di kawasan Wisata Kampung Misik seluas

1,5 Ha disediakan petani untuk percontohan agroforestry antara tanaman jelutung, buah naga, dan tanaman hortikultura, seperti: tomat, cabe, bawang daun, kacang panjang, kangkung, bayam, dan sawi yang ditanam secara bergantian. Pada lokasi ini dilengkapi dengan beberapa alat Kegiatan seperti untuk mengukur curah hujan, kelembaban tanah, suhu tanah, tinggi muka air, dan pengukur penurunan muka tanah, sehingga obyek wisata ini dapat dijadikan sebagai wisata Kegiatan dan wisata pendidikan.

\section{c. Wisata Petik Buah}

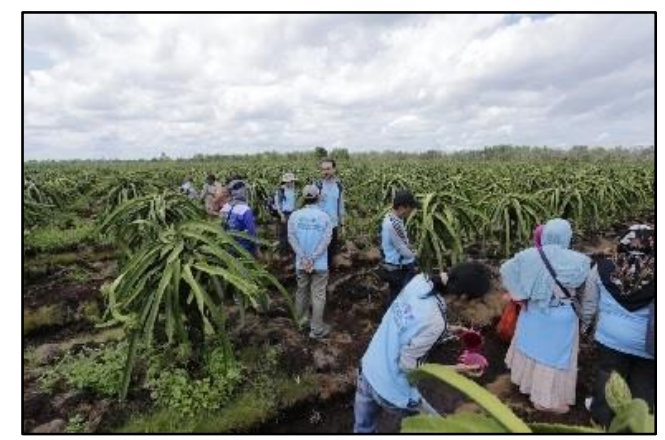

Gambar 7. Potensi wisata petik buah di lahan gambut

Obyek wisata ini merupakan salah satu atraksi wisata yang sudah berjalan sampai saat ini.
Wisata petik buah yang sudah berlangsung merupakan wisata massal, wisata khusus atau individu. Wisata massal yang sudah dilakukan adalah fieldtrip Seminar internasional gambut tahun 2018 dan wisata anak sekolah. Sedangkan wisata khusus atau individu sudah berlangsung setiap minggu, khususnya pada hari sabtu dan minggu. Wisatawan datang dari beberapa tempat, yang banyak dari kota Palangka Raya, namun ada juga yang datang dari Kabupaten Kapuas dengan waktu tempuh 2-3 jam.

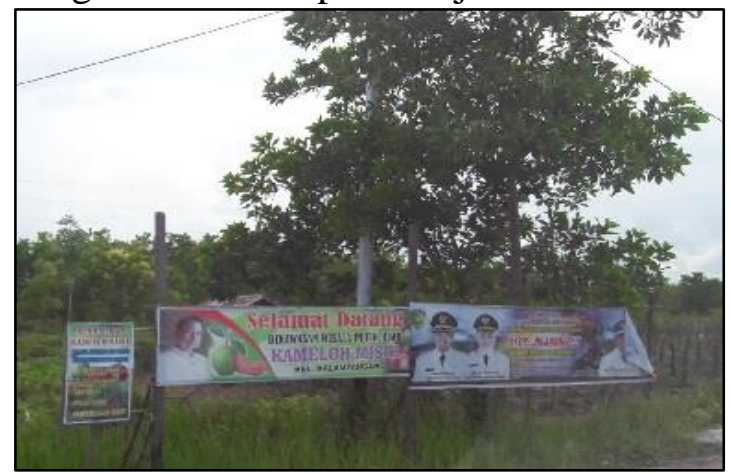

Gambar 8. Promosi wisata petik buah

d. Budidaya Jamur Tiram dan Cacing Tanah

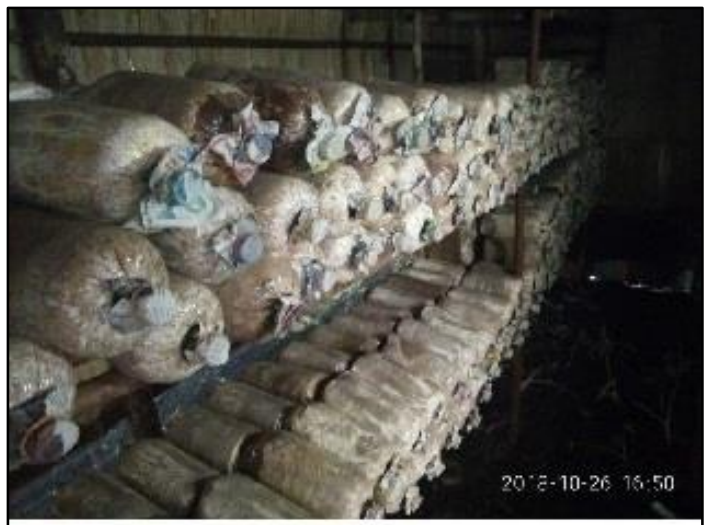

Gambar 5.9. Budidaya Jamur Tiram dan Budidaya Cacing Tanah

Upaya untuk mengurangi meluasnya pembukaan lahan gambut oleh masyarakat adalah dengan mengembangkan usaha budidaya tidak berbasis lahan, salah satunya adalah dengan mengembangkan usaha budidaya jamur. Pada kawasan Kampung Misik telah dilakukan pelatihan budidaya jamur tiram, dan dilakukan contoh ujicoba budidaya pada satu kelompok petani. Budidaya jamur tiram sudah memberikan hasil. Potensi peluang usaha jamur tiram 
masih sangat terbuka luas dan memberikan keuntungan.

Selain itu, budidaya cacing yang dilaksanakan pada tahun 2017 mulai diminati oleh petani untuk mengembangkannya. Budidaya cacing memberikan keuntungan kepada petani dengan memanfaatkan kascing sebagai pupuk kompos, baik yang digunakan langsung maupun yang diolah menjadi Pupuk Organik Cair (POC). Budidaya cacing memberikan beberapa keuntungan kepada petani, yaitu dapat mengurangi biaya produksi dengan menggantikan pupuk kimia dengan kascing, maupun dengan menjual kascing dan cacing.

Budidaya cacing tanah dimaksudkan sebagai langkah awal untuk melakukan budidaya dengan teknik pengolahan lahan tanpa bakar (PLTB) terutama dilahan gambut. Sisa pengolahan lahan baik serasah, ranting, dau maupun pohon dapat dicacah menjadi lebih halus dengan mesin pencacah yang sudah disiapkan oleh pelaksana kegiatan (Gambar 5.10). Limbah pengolahan yang telah dicacah, terbukti dapat menjadi pakan budidaya cacing tanah yang dilakukan oleh 2 (dua petani). Cacing hasil budidaya ini dapat dimanfaatkan untuk sumber protein dalam pengolahan pakan ikan. Limbah budidaya cacing (disebut kascing), berpotensi menjadi pupuk organik bagi petani.

Bagi pengembangan wisata, budidaya jamur dan budidaya cacing dapat dijakdikan sebagai wisata edukasi, yaitu usaha budidaya dengan mengurangi tekanan beban terhadap lahan gambut.

\section{e. Pengembangan Taman Hias}

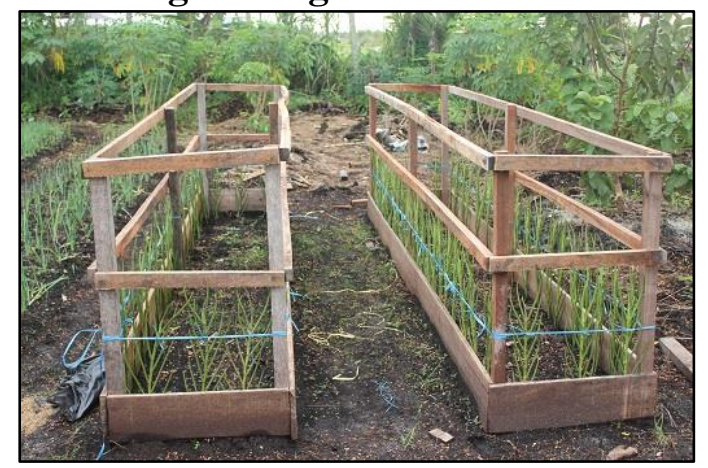

Gambar 11. Penanaman anggrek Vanda Douglas
Keindahan dan kenyamanan adalah salah satu yang diinginkan oleh wisatawan ketika mengunjungi suatu tujuan wisata. Keindahan kawasan wisata dapat dibuat dengan membuat taman-taman bunga, selain memberikan keindahan dan kenyamanan kepada wisatawan. Taman bunga yang dikembangkan pada saat ini adalah budidaya anggrek potong. Selain memberikan keindahan pada kawasan wisata, anggrek potong juga memberikan keuntungan ekonomi kepada masyarakat petani yang mendiami kawasan wisata ini.

Selain pengembangan tanaman anggrek potong, akan dikembangkan pula tanaman refugia, tanaman dengan bunga yang cantik namun dapat mengendalikan hama yang menyerang tanaman yang ramah lingkungan. Tanaman bunga yang berpotensi besar sebagai tanaman refugia adalah tanaman bunga matahari, tanaman kenikir, dan tanaman bunga kertas (Zinnia). Kelebihan tanaman bunga kertas adalah berbunga dan mekar setiap hari serta memiliki bunga berwarna-warni.

Sebagai bagian dari wisata pendidikan dan wisata restorasi, atraksi wisata lainnya yang dapat dikembangkan pada kawasan ini adalah pembibitan dan penanaman pohon. Penanaman pohon dapat dilakukan pada kawasan-kawasan yang seharusnya tidak diijinkan dibuka untuk budidaya, atau pada kawasan untuk revegetasi. Untuk pengembangan atraksi atau obyek wisata ini, diperlukan pemetaan wilayah atau kawasan sehingga dapat direncanakan zonasi setiap obyek wisata.

Tabel 1, merupakan atraksi wisata yang dapat dikembangkan di Kawasan Kampung Misik.

B. Accessibility, atau aksesibilitas adalah komponen penting kedua yang diperlukan dalam kegiatan pariwisata. Transportasi dan jasa transportasi merupakan akses penting dalam pariwisata. Akses didentikan dengan kemudahan bergerak dari satu daerah/tempat ke daerah/tempat lainnya. 
Tabel 1. Atraksi Wisata di Kampung Misik dan Kebutuhan Pengembangannya.

\begin{tabular}{l|l|l}
\hline \multicolumn{1}{c|}{ Obyek Wisata } & Kondisi Lingkungan & \multicolumn{1}{c}{$\begin{array}{c}\text { Kebutuhan } \\
\text { Pengembangan }\end{array}$} \\
\hline Susur Kanal & Tersedia & $\begin{array}{l}\text { Alat transportasi, } \\
\text { berupa jukung/kelotok } \\
\text { atau rakit }\end{array}$ \\
\hline Agroforestry & $\begin{array}{l}\text { Tersedia, dan sesuai } \\
\text { untuk dikembangkan }\end{array}$ & $\begin{array}{l}\text { Pengaturan tanaman } \\
\text { hortikultura, dan } \\
\text { pengembangan } \\
\text { kawasan lainnya }\end{array}$ \\
\hline Petik Buah & $\begin{array}{l}\text { Tersedia dan sesuai untuk } \\
\text { dikembangkan }\end{array}$ & $\begin{array}{l}\text { Pengaturan penanaman } \\
\text { agar buah selalu } \\
\text { tersedia sepanjang } \\
\text { musim }\end{array}$ \\
\hline $\begin{array}{l}\text { Budidaya Jamur Tiram } \\
\text { dan Cacing Tanah }\end{array}$ & $\begin{array}{l}\text { Sesuai untuk } \\
\text { dikembangkan }\end{array}$ & $\begin{array}{l}\text { Diperluas dan } \\
\text { dikembangkan dalam } \\
\text { skala besar }\end{array}$ \\
\hline Taman Bunga & $\begin{array}{l}\text { Sesuai untuk } \\
\text { dikembangkan }\end{array}$ & $\begin{array}{l}\text { Pengaturan zonasi dan } \\
\text { kawasan yang sesuai }\end{array}$ \\
\hline $\begin{array}{l}\text { Pembibitan dan } \\
\text { Penanaman pohon }\end{array}$ & $\begin{array}{l}\text { Sesuai dan cocok untuk } \\
\text { dikembangkan }\end{array}$ & $\begin{array}{l}\text { Pemetaan } \\
\text { lokasi/kawasan, } \\
\text { pemilihan bibit }\end{array}$ \\
\hline
\end{tabular}

Kawasan wisata Kampung Misik merupakan bagian dari Kelurahan Kalampangan, Kabupaten Sabangau Kota Palangka Raya. Akses jalan Kampung Misik ke pusat Kota Palangka Raya dapat ditempuh dengan transportasi darat melalui jalan beraspal dengan kondisi yang baik. Namun untuk kemudahan bergerak, saat ini belum tersedia angkutan umum dari pusat kota menuju kawasan Kampung Misik, sehingga saat ini wisatawan untuk mencapai lokasi wisata tersebut harus menggunakan kendaraan pribadi maupun carter.

Untuk memasuki kawasan Kampung Misik menuju obyek wisata yang tersedia, jalan masih rusak. Belum tersedia jalan setapak untuk menyusuri kanal atau mengunjungi obyek yang satu dengan obyek yang lain. Hasil ujicoba kunjungan wisata yang dilakukan memberikan masukan bahwa masih diperlukan perbaikan jalan dan pembuatan jalan setapak menuju obyek wisata.

Tabel 2. Aksesibilitas menuju Kampung Misik

\begin{tabular}{l|l|l}
\hline \multicolumn{1}{c|}{ Aksesibilitas } & \multicolumn{1}{c|}{ Kondisi } & \multicolumn{1}{c}{$\begin{array}{c}\text { Keamanan } \\
\text { dan } \\
\text { Kenyamanan }\end{array}$} \\
\hline Jalan Utama & Tersedia, Baik, mudah ditempuh & Aman, nyaman \\
\hline $\begin{array}{l}\text { Jalan Pendukung menuju } \\
\text { Obyek wisata }\end{array}$ & Tersedia, Rusak, sulit ditempuh & $\begin{array}{l}\text { Aman, tidak } \\
\text { nyaman }\end{array}$ \\
\hline Jalan Setapak & Tidak Tersedia & - \\
\hline Tanspotrasi Umum & Tidak Tersedia & - \\
\hline Taxi & Tersedia dari luar kawasan wisata & Aman \\
\hline Terminal & Tidak Tersedia & - \\
\hline
\end{tabular}

C. Amenity, atau amenitas adalah elemen dalam tujuan wisata atau berhubungan dengan tujuan wisata yang memungkinkan wisatawan tinggal di kawasan wisata untuk 
menikmati atau berpartisipasi dalam atraksi yang disediakan. Amenitas merupakan sarana dan prasarana yang disediakan agar wisatawan dapat tinggal lebih lama pada kawasan wisata, sehingga dapat meningkatkan perekonomian di sekitar kawasan dengan semakin banyaknya uang yang beredar di kawasan wisata.

Prasarana kepariwisataan (tourism infrastructures) adalah semua fasilitas yang memungkinkan agar sarana kepariwisataan dapat hidup dan berkembang serta dapat memberikan pelayanan pada wisatawan untuk memenuhi kebutuhan yang beranekaragam. Prasarana wisata dapat berupa: jalan, air bersih, terminal, lapangan udara, komunikasi dan listrik. Prasarana yang menyangkut ketertiban dan keamanan agar kebutuhan terpenuhi dengan baik seperti apotik, kantor pos, bank, rumah sakit, polisi.

Sarana kepariwisataan (tourism suprastructure) adalah pelayanan kepada wisatawan baik secara langsung atau tidak langsung, seperti: travel agen, transportasi, akomodasi/ penginapan, dan restoran.
Jarak antara pusat Kota Palangka Raya dengan kawasan Kampung Misik hanya berjarak kurang lebih $25 \mathrm{~km}$ atau memerlukan waktu tempuh 30 menit, sehingga akomodasi berupa penginapan atau hotel yang tersedia di Kota Palangka Raya jumlah dan ragamnya cukup luas. Namun tujuan dari pengembangan wisata adalah agar wisatawan membelanjakan uang sebanyak-banyaknya pada kawasan wisata sehingga memberikan keuntungan ekonomi kepada masyarakat di sekitar kawasan wisata, perlu dikembangkan akomodasi atau penginapan yang berbasis masyarakat yang berada di sekitar kawasan.

Rumah makan, toko oleh-oleh/cendera mata yang tersedia berada di luar kawasan wisata Kampung Misik, sehingga perlu dikembangkan rumah makan pada kawasan wisata dengan pengelolaannya dilakukan oleh masyarakat setempat.

Sarana lainnya yang tersedia adalah gazebo dan toilet umum, dibangun melalui kegiatan BRG pada tahun 2017 dan 2018. Pada tahun 2017 telah dibangun sebanyak 4 (empat) unit gazebo, dan pada tahun 2018 dibangun sebanyak 6 (enam) unit.

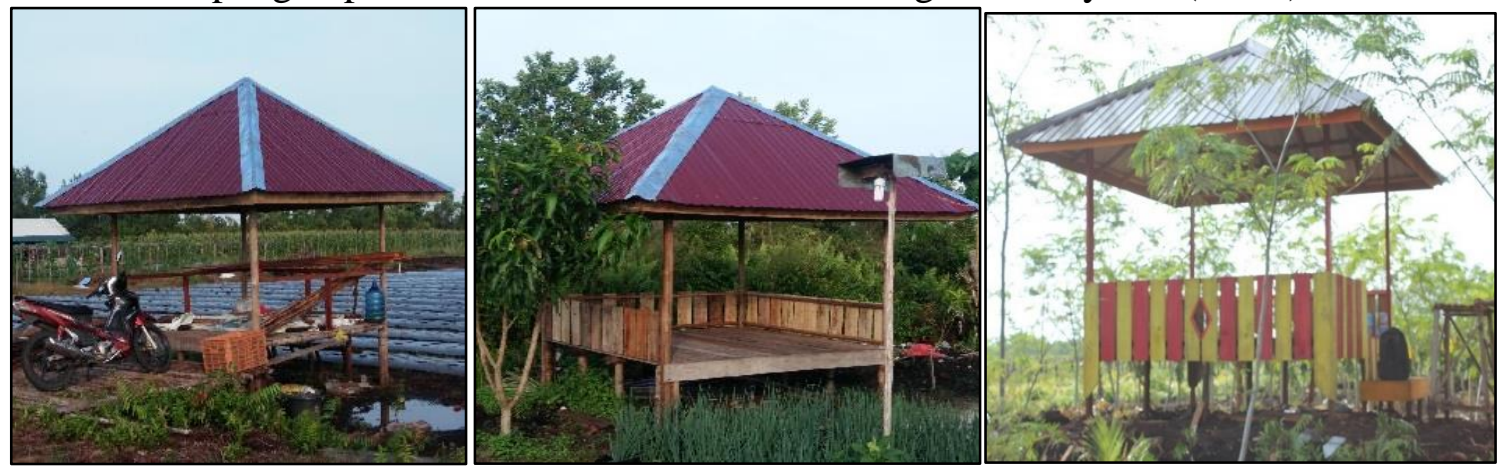

Gambar 12. Gazebo yang telah dibangun di Kampung Misik

Pada tahun 2018 telah dibangun 2 (dua) unit toilet umum, dengan 2 WC pada masingmasing unitnya. Pembangunan Gazebo dan toilet umum yang dilaksanakan oleh BRG ini merupakan stimulan, untuk kebutuhan pengembangan kawasan wisata diperlukan pembangunan yang lebih banyak.

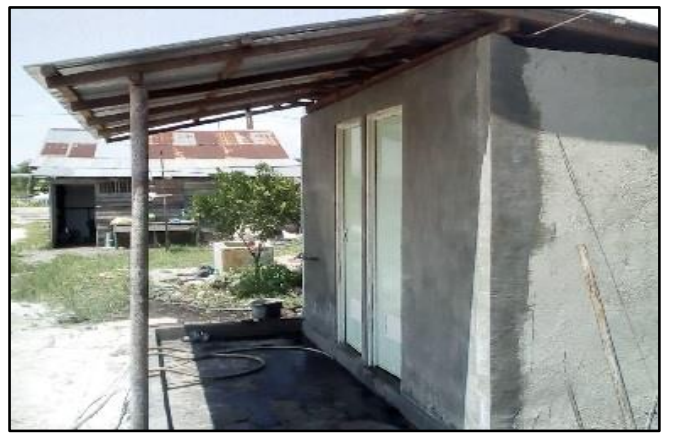

Gambar 13. Pengembangan fasilitas umum 
Berbagai pihak dapat dilibatkan dalam pengembangan kawasan wisata, khususnya dalam penyediaan sarana wisata, misalnya dengan pihak perbankan dan perusahaan swasta lainnya yang diusulkan oleh masyarakat.

Masyarakat secara swadaya telah membangun musholla untuk kebutuhan masyarakat setempat. Guna memenuhi kebutuhan wisatawan dalam jumlah yang besar, diperlukan pengembangan musholla dengan penyediaan air bersih yang memadai.

Travel agen dan pemandu wisata (guide) sudah tersedia di Kota Palangka Raya dalam jumlah yang terbatas, dan belum tersedia pemandu wisata pada Kawasan Wisata Kampung Misik. Oleh karenanya, dalam kegiatan Kajian Ekowisata ini dilaksanakan Sosialisasi Budaya Wisata, dan Pelatihan Pemandu Wisata. Kedua kegiatan tersebut

dimaksudkan untuk membekali masyarakat di lokasi wisata dalam memahami tentang budaya wisata, dan mempersiapkan masyarakat, terutama kelompok pemuda, untuk menjadi guide/pemandu wisata. Kedua kegiatan tersebut berjalan dengan baik, dan telah memberikan pemahaman dan pembekalan untuk menjadi pemandu wisata.

Oleh-oleh atau cendera mata merupakan bagian penting dari kegiatan wisata, oleh karenanya perlu menciptakan oleh-oleh atau cendera mata yang khas lahan gambut. Saat ini oleh-oleh yang bisa dibawa oleh wisatawan adalah buah-buahan seperti buah naga, jambu kristal, atau melon yang merupakan hasil dari wisata petik buah. Beberapa oleh-oleh yang dapat dikembangkan adalah: anyaman purun karena bahan dasarnya tersedia di alam, pengolahan buah naga, dan pengolahan jamur tiram.

Tabel 3. Jenis amenitas dan kondisinya dalam kaitan wisata di Kampung Misik

\begin{tabular}{|c|c|}
\hline Jenis Amenitas & Kondisi \\
\hline Hotel/Penginapan & $\begin{array}{l}\text { Tersedia di Kota Palangka Raya } \\
\text { Belum tersedia di Kawasan Wisata }\end{array}$ \\
\hline Rumah makan & $\begin{array}{l}\text { Tersedia di Kota Palangka Raya } \\
\text { Belum tersedia di Kawasan Wisata }\end{array}$ \\
\hline Agen Perjalanan & $\begin{array}{l}\text { Tersedia di Kota Palangka Raya } \\
\text { Kawasan Wisata Kampung Misik belum } \\
\text { masuk dalam tujuan wisata }\end{array}$ \\
\hline Pemandu Wisata Lokal & $\begin{array}{l}\text { Tersedia di Kota Palangka Raya dalam jumlah } \\
\text { terbatas } \\
\text { Belum banyak yang mampu berbahasa asing }\end{array}$ \\
\hline $\begin{array}{l}\text { Toko oleh-oleh/cendera } \\
\text { mata }\end{array}$ & $\begin{array}{l}\text { Belum tersedia oleh-oleh/cendera mata khas } \\
\text { kawasan wisata lahan gambut selain buah }\end{array}$ \\
\hline Toilet Umum & $\begin{array}{l}\text { Tersedia } 2 \text { (dua) buah, di rumah Pak Ismail } \\
\text { (Ketua RT) dan Pak Mahfud (berdekatan } \\
\text { dengan Musholla) } \\
\text { Perlu tambahan jumlah }\end{array}$ \\
\hline Musholla & $\begin{array}{l}\text { Tersedia musholla dengan kapasitas terbatas } \\
\text { Perlu pengembangan }\end{array}$ \\
\hline
\end{tabular}

D. Ancillary, atau pelayanan tambahan yang disediakan oleh lembaga pemerintah maupun swasta baik untuk wisatawan maupun pelaku wisata. Pelayanan meliputi: pemasaran, pembangunan fisik, serta lembaga pengelolaan pariwisata. Tersedianya ancilliary pada lokasi 
kawasan wisata memberikan rasa aman, nyaman, dan keselamatan bagi wisatawan.
Pelayanan keamanan yang disediakan oleh kepolisian tersedia sampai pada tingkat kelurahan.

Tabel 4. Layanan tambahan untuk mendukung pengembangan wisiata di lahan gambut

\begin{tabular}{|c|c|}
\hline Jenis Ancillary & Kondisi \\
\hline Layanan Keamanan & $\begin{array}{l}\text { Tersedia Polisi dan Babinsa pada tingkat } \\
\text { kelurahan } \\
\text { Belum tersedia di Kawasan Wisata }\end{array}$ \\
\hline Layanan Kesehatan & $\begin{array}{l}\text { Tersedia rumah sakit pada tingkat kelurahan } \\
\text { Belum tersedia di Kawasan Wisata }\end{array}$ \\
\hline Pengelolaan sampah & Belum tersedia pengelolaan sampah \\
\hline Air Bersih & $\begin{array}{l}\text { Tersedia pada setiap rumahtangga masyarakat } \\
\text { di kawasan Kampung Misik, dengan fasilitas } \\
\text { sumur bor } \\
\text { Air bersih dan jernih } \\
\text { Belum tersedia jaringan air bersih }\end{array}$ \\
\hline Jaringan Komunikasi & Tersedia jaringan komunikasi \\
\hline Jaringan Listrik & Tersedia jaringan listrik \\
\hline
\end{tabular}

\section{Dukungan Masyarakat dan} Stakeholders

Pengembangan kawasan wisata membutuhkan dukungan dari berbagai pihak, baik pemerintah daerah maupun masyarakat setempat. Kegiatan yang dilakukan untuk mengatahui dukungan pemerintah daerah, swasta, dan masyarakat dilaksanakan melalui kegiatan: 1) workshop terbatas untuk persiapan penyusunan masterplan; 2) riset lapangan melalui survei dan FGD; dan 3) Ujicoba kunjungan wisata.

\section{a. Workshop Terbatas Untuk Persiapan Penyusunan Masterplan}

Workshop Terbatas dilaksanakan pada tanggal 26 Nopember 2018, dengan peserta berasal dari Pemerintah daerah (yaitu: Dinas Pariwisata Kota palangka Raya, Dinas Pemberdayaan Masyarakat Kota Palangka Raya, TRGD Provinsi Kalimantan Tengah), Lurah Kalampangan dan Kameloh Baru, Tohoh masyarakat, Pelaku Usaha Wisata, Dosen Fakultas Pertanian UPR, Balai Taman Nasional Sebangau, dan WWF Indonesia.

Narasumber Workshop adalah Kepala Dinas Pariwisata kota Palangka Raya, Dosen Departemen Lansekap Fakultas Pertanian Institut Pertanian Bogor, dan Ketua Tim
Kajian Restorasi Gambut Terintegrasi Pada Lahan Gambut.

Berdasarkan Rencana Induk Pembangunan Kepariwisataan Tahun 2017-2028 (RIPPAR) Kota Palangka Raya yang telah dituangkan dalam Peraturan Daerah Nomor 11 Tahun 2017, menyebutkan 4 Kawasan Strategis Pariwisata (KSP) di Kota Palangka Raya, yaitu:

a. KSP 1-KSP Sei Gohong, dengan tema pengembangan pariwisata Konserva-si

b. KSP 2-KSP Tumbang Tahai, dengan tema pengembangan pariwisata Edukasi (pendidikan budaya, pendidikan konservasi)

c. KSP 3-KSP Pahandut, dengan tema pengembangan pariwisata Rekreatif ( wisata kuliner, wisata keluarga), dan

d. KSP 4-KSP Kalampangan, dengan tema pengembangan pariwisata berbasis lingkungan atau Ekowisata.

Berdasarkan pembagian kawasan tersebut, Kelurahan Kalampangan berada pada KSP 4 dengan tema pariwisata berbasis lingkungan atau ekowisata, hal ini sejalan dengan konsep yang akan dikembangkan yaitu menjadikan Kawasan Kampung Misik menjadi Kawasan ekowisata.

Dukungan terhadap pengembangan Kawasan wisata ini juga didapat dari pelaku 
usaha pariwisata melalui sosialisasi dan memasukkan Kawasan Misik sebagai salah tujuan wisata di Kota Palangka Raya dan Kalimantan Tengah. Sosialisasi dan publikasi Kawasan Misik sebagai tujuan wisata sangat diperlukan untuk pengembangan kawasan.

Narasumber yang berasal dari Departemen Lansekap Fakultas Pertanian IPB menyampaikan bahwa Kawasan Misik memiliki potensi untuk dikembangkan sebagai tujuan wisata berbasis lingkungan atau ekowisata, dan dapat dikembangkan menjadi agroekowisata.

Pengembangan kawasan ini menjadi tujuan wisata diperlukan perencanaan yang lebih detail dalam bentuk masterplan, sehingga ditetapkan zonasi-zonasi dari setiap atraksiatraksi yang yang tersedia dan dapat dikembangkan di kawasan Misik. Penyusunan masterplan ini membutuhkan dukungan dari pemerintah daerah dan pemangku kepentingan lainnya yang memiliki kompetensi dibidangnya, oleh karenanya perencanaan ini perlu ditindaklanjuti, dan Perguruan Tinggi (UPR) dapat menjembatani antara pemerintah daerah dan masyarakat dalam rangka penyusunannya.

\section{b. Ujicoba Kunjungan Wisata}

Ujicoba kunjungan wisata ke Kawasan Misik dilaksanakan dengan mengundang 45 orang mahasiswa Fakultas Pertanian Universitas Palangka Raya. Penentuan peserta ujicoba dimaksudkan agar dapat memberikan masukkan untuk pengembangan kawasan wisata Misik.

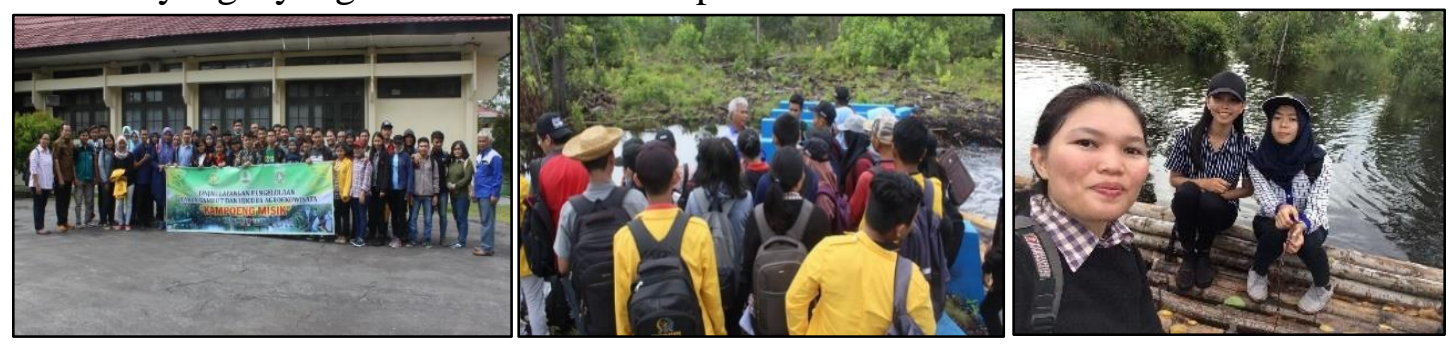

Gambar 15. Kegiatan uji coba wisata di lahan gambut

Sebagian besar peserta menyatakan bahwa obyek wisata keseluruhan di Kawasan Misik menarik untuk dijadikan kawasan wisata, dan 51 persen peserta menyatakan Tanaman Buah serta kanal merupakan obyek yang sangat menarik.

Dari aspek aksesibiltas, peserta menyatakan bahwa jalan masuk, ketersediaan sarana transportasi, serta rambu-rambu penunjuk jalan dan lokasi dianggap kurang mendukung. Jalan masuk masih berupa tanah yang sebagian tempat masih berlubang dan tergenang pada saat hujan, belum tersedia transpotasi umum yang dapat mengantarkan wisatawan untuk datang ke lokasi, dan belum tersedia penunjuk jalan, dan penanda obyek wisata. Namun demikian peserta merasa puas dan nyaman melaksanakan wisata ke kawasan Misik, dan akan mengunjungi kawasan ini kembali.

Masukan dan saran yang diberikan oleh peserta untuk pengembangan kawasan Misik sebagai berikut: a. Perbaikan jalan masuk, agar lebih nyaman menuju obyek wisata.

b. Transportasi umum ke kawasan wisata Misik, sehingga tanpa kendaraan pribadi dapat menuju ke lokasi.

c. Penambahan toilet umum dan kebersihannya yang terjaga.

d. Perluasan musholla.

e. Tempat sampah sebaiknya tersedia pada banyak tempat

f. Jumlah gazebo yang lebih banyak pada onyek-obyek wisata

g. Sebaiknya disediakan Spot berfoto pada tempat-tempat yang indah.

\section{Strategi Pengembangan Ekowisata}

Kawasan Kampung Misik membutuhkan dukungan untuk pengembangannya sebagai tujuan wisata. Hasil analisis terhadap Kekuatan dan Kelemahan serta Peluang dan Tantangan dalam pengembangan disajikan pada Tabel 5. 
Tabel 5. Analisis SWOT pengembangan wisata di kampung Misik

\begin{tabular}{|c|c|c|}
\hline Eksternal & $\begin{array}{l}\text { Kekuatan: } \\
\text { 1. Dukungan } \\
\text { masyarakat dan } \\
\text { tokoh masyarakat } \\
\text { yang sangat besar } \\
\text { 2. } \text { Masyarakat yang } \\
\text { guyub dan dapat } \\
\text { bekerjasama } \\
\text { 3. Pengelolaan mudah } \\
\text { karena berada pada } \\
\text { satu kawasan dan } \\
\text { terdapat satu pintu }\end{array}$ & 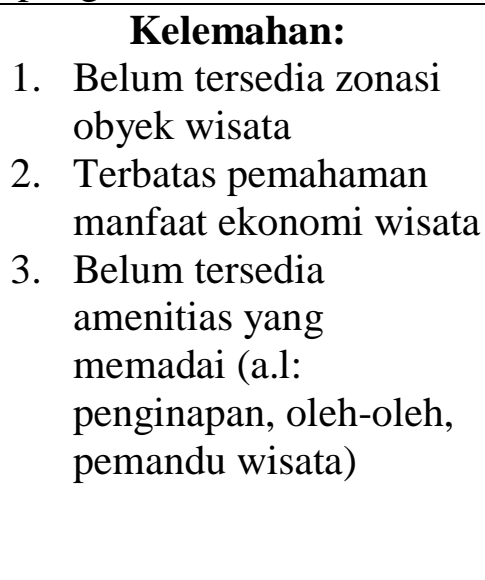 \\
\hline $\begin{array}{l}\text { Peluang: } \\
\text { 1. Lahan Gambut } \\
\text { merupakan obyek yang } \\
\text { unik dan khas } \\
\text { 2. Belum banyak tersedia } \\
\text { kawasan wisata di Kota } \\
\text { Palangka Raya } \\
\text { 3. Termuat dalam } \\
\text { RIPPAR Kota Palangka } \\
\text { Raya sebagai salah satu } \\
\text { Kawasan Strategis } \\
\text { Pariwisata }\end{array}$ & \begin{tabular}{ll}
\multicolumn{1}{c}{ Strategi SO: } \\
1. & Memperluas \\
sosialisasi dan \\
publikasi baik \\
melalui media \\
massa maupun \\
media sosial \\
2. \\
Penyusunan konsep \\
wisata dan \\
Pengembangan daya \\
tarik wisata berbasis \\
gambut
\end{tabular} & $\begin{array}{l}\text { Strategi WO: } \\
\text { 1. Menyusun Perencanaan } \\
\text { tataruang dan } \\
\text { masterplan Kawasan } \\
\text { 2. Dengan dukungan } \\
\text { pemerintah } \\
\text { mengembangkan } \\
\text { aksesibiltas } \\
\text { 3. Mengembangkan } \\
\text { amenitas berbasis } \\
\text { masyarakat }\end{array}$ \\
\hline $\begin{array}{l}\text { Tantangan: } \\
\text { 1. Keberlanjutan obyek } \\
\text { wisata, terutama wisata } \\
\text { petik buah } \\
\text { 2. Fungsi lahan pada } \\
\text { sebagian kawasan } \\
\text { adalah Hutan Lindung } \\
\text { 3. Belum tersedia saran } \\
\text { transportasi umum }\end{array}$ & $\begin{array}{l}\text { Strategi ST: } \\
\text { 1. Melakukan jadwal } \\
\text { penanaman agar buah } \\
\text { untuk wisata petik } \\
\text { buah tetap tersedia } \\
\text { sepanjang waktu } \\
\text { 2. Pemetaan wilayah } \\
\text { 3. Penerapan Peraturan } \\
\text { dan sanksi } \\
\text { 4. Atraksi penanaman } \\
\text { pohon sebagai bagian } \\
\text { dari wisata restorasi }\end{array}$ & $\begin{array}{l}\text { Strategi WT: } \\
\text { 1. Penetapan zonasi } \\
\text { budidaya dan } \\
\text { konservasi } \\
\text { 2. } \text { Sosialisasi } \\
\text { Peningkatan } \\
\text { kesadaran secara } \\
\text { berkesinambungan } \\
\text { kepada masyarakat } \\
\text { tentang pentingnya } \\
\text { pengembangan } \\
\text { ekowisata } \\
\text { 3. Meningkatkan } \\
\text { kerjasama antara } \\
\text { masyarakat, pelaku } \\
\text { wisata dan } \\
\text { pemerintah daerah }\end{array}$ \\
\hline
\end{tabular}

\section{Kesimpulan}

Perkembangan pelaksanaan kegiatan Kajian Potensi Ekowisata Terintegrasi sebagai berikut:

1. Dukungan Lurah Kelurahan Kalampangan, dan masyarakat Kampung Misik RT 7 Kelurahan Kalampangan yang merupakan lokasi pelaksanaan kegiatan sangat penting.

2. Kegiatan yang direncanakan dilaksanakan telah dilaksanakan, dengan beberapa penundaan kegiatan terkait dengan kondisi musim kemarau. 
3. Penyadartahuan tentang pentingnya restorasi gambut sangat penting kepada masyarakat sasaran sangat penting agar masyarakat dapat melaksanakan kegiatan Restorasi Gambut dengan baik.

4. Petani kunci tetap memainkan peranan penting untuk masyarakat dalam menerima program restorasi yang disampaikan, selain program yang ditawarkan dapat memenuhi harapan mereka terkait dengan pendapatan.

5. Koordinasi kegiatan restorasi yang didanai Badan Restorasi Gambut atau kegiatan lainnya, terutama pada kawasan yang sama sangat penting agar tidak terdapat persepsi negatif masyarakat terhadap kegiatan.

6. Terdapat beberapa potensi objek agroekowisata yang dapat dikembangkan lebih baik.

7. Beberapa fasilitas pendukung telah mulai dibangun dan diperlukan pengembangan, terutama infrastruktur jalan.

\section{Ucapan Terima Kasih}

Ucapan terima kasih disampaikan kepada Badan Restorasi Gambut yang telah mendanai kegiatan melalui Tahun Anggaran 2017 dan 2018.

\section{Daftar Pustaka}

Bahaire T, Elliot-White M. 1999. The Application of GIS in sustainable tourism planning: A review. Departement of Tourism and Environmental, University of Lincolnshire \& Humberside Brayford Pool.

Barchia MF. 2006. Gambut: Agroekosistem dan transformasi karbonYogyakarta: Gadjah Mada University Press.

Barus B, Wiradisastra US. 1997. Sistem Informasi Geografis: Sarana manajemen sumberdaya. Bogor: Laboratorium Penginderaan Jauh dan Kartografi Jurusan Tanah, Fakultas Petanian IPB.

Buckman HO, Brady NC. 1982. Ilmu tanah. Jakarta : Bhatara Karya Aksara.
Budiyanto E. 2010. Sistem Informasi Geografis dengan ArcView GISYogyakarta: Penerbit Andi.

Cooper, C., Fletcher, J., Gilbert, D.G. and Wanhill, S. (2005). Tourism; Principle and Practive, Third Edition, Harlow. Prentice Hall.

Damanik J, Weber HF. 2006. Perencanaan ekowisata: Dari teori ke aplikasi. Yogyakarta: penerbit ANDI Offset.

Dobbs C, Escobeda FJ, Zipperer WC. 2011. A framework for developing urban forest ecosystem services and goods indicator. Landscape and Urban Planning99: 196206.

Eriyatno, Sofyar F. 2007. Riset kebijakan: Metode Kegiatan untuk pascasarjana. Bogor: IPB Press.

Erwin KL. 2009. Wetlands and global climate change: The role of wetlands restoration in a changing world. Wetlands Ecology Manage 17: 71-84.

Fandeli C, Muhammad. 2009. Prinsip-prinsip dasar mengkonservasi lanskap. Yogyakarta: Gadjah Mada University press.

Font X, Tribe J (editors). 2000. Forest tourism and recreation: Case studies in environmental management . New York: Cabi Publishing.

Gilbert R. 2003. Ecotourism and education for sustainability: A critical approach. International Review for Environmental Strategies4 (1): 75-83.

Gold SM. 1980. Recreation planning and design. New York: McGraw-Hill Book Co.

Gunn CA. 1994. Tourism planning: Basics, concept, cases. London: Taylor \&Francis ltd

Harjdowigeno W, Widiatmaka. 2007. Evaluasi kesesuaian lahan dan perencanaan tata guna lahan. Yogyakarta: Gadjah Mada University Press.

Holden A. 2000. Environmental and tourism. London: Routledge.

Inskeep E. 1991. Tourism planning: An integrated and sustainable development 
approach.New York: van Nostrand Reinhold.

MacKinnon K, Hatta G, Halim H, Mangalik $\mathrm{A}$; Editor seri: Kartikasari $\mathrm{SN}$; Alih Bahasa: Tjitrosoepomo G, Kartikasari SN, Widyantoro A. 2000. Ekologi Kalimantan.Jakarta: Prenhallindo.

MacKinnon K, MacKinnon J, Child G, Thorsell J. 1986. Pengelolaan kawasanyang dilindungi di daerah tropika. . Yogyakarta:Gadjah Mada University Press.

McKinney RA, Charpentier MA. 2009. Extent, properties, and landscape setting of geographically isolated wetlands in urban southern New England watersheds. Wetland Ecology Manage 17: 331-344.

McKinney RA, Raposa KB, Cournayer EM. 2011. Wetlands as habitat in urbanizing landscape: Patterns of bird abundance and occupancy. Landscape and Urban Planning100: 144-152.

Noor M. 2001. Pertanian lahan gambut: Potensi dan kendala. Yogyakarta: Kanisius.

Nurisyah S, Pramukanto Q, Wibowo S. 2003. Daya Dukung dalam perencanaan tapak.. Bahan Perkuliahan AGR 362 (Analisis dan Perencanaan Tapak) PS Aristektur Lanskap. Bogor : Fakultas Pertanian, Institut Pertanian Bogor.

Payangan, O.R., 2005. Analisis Faktor-faktor Yang Mempengaruhi Kinerja Pemasaran Pariwisata di Sulawesi Selatan. Disertasi. PPs Unhas Makassar (Tidak dipublikasikan).

Pitana, I Gede dan Surya Diarta, I Ketut (2009). Pengantar Ilmu Pariwisata. Yogyakarta. Andi Offset.

Posa MRC, Wijedasa LS, Corlett RT. 2011. Biodiversity and conservation of tropical peat swamp forests. Bioscience Journal 61: 49-57.

Ramsar Convention Secretariat. 2007. Inventory, assessment, and monitoring: An Integrated Framework for wetland nal of Tourism management31: 739-7 43. inventory, assessment, and monitoring. Ramsar handbooks for the wise use of wetlands 3rd edition vol. 11. Gland, Switzerland: Ramsar Convention Secretariat.

Rieley JO. 2007. Environmental and economic importance of lowland tropical peatlands of Southeast Asia: Focus on Indonesia. Dalam Wosten H, Radjagukguk B. Open Science Meeting 2005, Session on The Role of Tropical Peatlands in Global Change Processes, Science and Society: New Challenges and Opportunities. Yogyakarta 27-29 September 2005. Yogyakarta: Andi Offset.

Simonds JO, Starke BW. 2006. Landscape architecture: A Manual of environmental planning and design. New York: McGraw-Hill Book Co.

Smith SLJ. 1989. Tourism analysis : A handbook. England : Longman Group UK Limited.

Syukur M. 2006. Komposisi dan asosiasi jenis pohon berdasarkan ketebalan gambut pada hutan wisata rawa gambut Kabupaten Sintang Kalimantan Barat.[tesis]. Samarinda: Program Pascasarjana, Universitas Mulawarman. Wahyunto, Rirung S, Suparto, Subagjo H. 2005. Sebaran gambut dan kandungan karbon di Sumatra dan Kalimantan. Bogor: Wetlands InternationalIndonesia Pragramme.

Widjaya-Adhi IPG. 1993. Potensi lahan rawa di Kalimantan, pengelolaan dan teknologi pengembangannya. Dalam prosiding Temu Konsultasi Sumber Daya Lahan untuk Pembangunan Wilayah Kalimantan. Palangkaraya, 5-6 Oktober 1993. Bogor: pusat Kegiatan Tanah dan Agroklimat.

Wu YY, Wang HL, Ho YF. 2010. Urban ecotourism: Defining and assessing dimensions using fuzzy number construction. Jour 